Article

\title{
Compositional Characterization and Chronology of Roman Mortars from the Archaeological Site of Arroyo De La Dehesa De Velasco (Burgo De Osma- Ciudad De Osma, Soria, Spain)
}

\author{
Ainhoa Alonso-Olazabal 1,*, Luis Angel Ortega 1(D, Maria Cruz Zuluaga ${ }^{1}$ (D), \\ Graciela Ponce-Antón ${ }^{1}$ (D) Javier Jiménez Echevarría ${ }^{2}$ and Carmen Alonso Fernández ${ }^{2}$ \\ 1 Department of Mineralogy and Petrology, University of Basque Country UPV/EHU, Sarriena s/n, \\ 48940 Leioa, Bizkaia, Spain; luis.ortega@ehu.eus (L.A.O.); mcruz.zuluaga@ehu.eus (M.C.Z.); \\ graciela.ponce@ehu.eus (G.P.-A.) \\ 2 Cronos S.C. Arqueología y Patrimonio, Centro Europeo de Empresas e Innovación, Módulo 3, \\ 09007 Burgos, Spain; jj@cronossc.es (J.J.E.); ca@cronossc.es (C.A.F.) \\ * Correspondence: ainhoa.alonso@ehu.es; Tel.: +34-946015450
}

Received: 25 March 2020; Accepted: 26 April 2020; Published: 28 April 2020

\begin{abstract}
This study characterises the mortar materials used in the construction of walls and floors at the Arroyo de la Dehesa de Velasco site, located near the Roman city of Uxama Argaela (the modern Burgo de Osma-Ciudad de Osma, Soria, Spain). Multilayer mortars have been characterised by petrographic, mineralogical (X-ray diffraction and scanning electron microscopy with energy dispersive analyses and geochemical analysis (X-ray fluorescence). Additionally, radiocarbon dating of the mortar binder fraction was performed in order to establish the chronology of the building in the absence of other archaeological chronological records. The results showed that similar siliceous aggregates and lime binders were used in the fabrication of multilayer system mortars. Some multilayer wall mortars show ceramic fragments or brick powder to produce hydraulic mortars and improve the resistance to moisture. The raw materials used for the construction of the site were of local origin and the construction was built during the first century $\mathrm{BC}$, according to radiocarbon dating.
\end{abstract}

Keywords: lime mortar; multilayer system; cocciopesto; radiocarbon dating; Roman period

\section{Introduction}

Mortars are an essential artificial material used since ancient times to support walls and substrates of buildings, and their durability is related to the nature of the components and manufacturing methods. Mortars consist of a mixture of aggregates and binder related both to the geographic location of the building and to the historical context in which the mortars were manufactured [1-8]. The study of mortars offers clues about raw materials and their provenance as well as on the manufacturing technology [9-17]. The characteristics of the mortars can be used to determine the chronological sequences of the construction [18-21] and they can be used for building dating [22-28]. Mortars also provide keys to restoration and conservation issues [29-33] and for the formulation of new composite materials [34-39]. Although the ancient Romans detailed the recipes and technological guidelines for building construction, putting them into practice by the craftsmen was no small feat $[40,41]$. According to the primary function or the finishing, different technical solutions were applied in historical buildings and constructions and these techniques were extensively used all around the Roman Empire.

The Roman archaeological site of Arroyo de la Dehesa de Velasco was accidentally discovered during the construction of the Duero motorway (A-11) between the towns of Burgo de Osma and 
Santiuste (Soria, Spain). It provides an excellent opportunity for the study of wall and floor structure mortars. The site is located in the eastern surroundings of the Roman city of Uxama Argaela. This city is in the plain of the medium-high course of the River Douro, close to the River Abión, where Quaternary materials are abundant as well as Paleogene and Neogene deposits [42]. The ancient city of Uxama Argaela was an important Celtiberian city occupied by Romans during the war against Numantia in northern Spain. The Romanisation of the region began slightly before the first century BC and intensified in the first century $\mathrm{AD}$, leading to the construction of a Roman city with such public buildings as forum, temple, basilica, baths, aqueduct and cisterns [43-45]. The economic potential of Uxama Argaela was attributable to its strategic location on one of the most important roads in the interior of the Iberian Peninsula, connecting Asturica Augusta (Astorga) to Caesar Augusta (Zaragoza) and connecting the city with other regions in Hispania and Gaul. During the second century AD, the city experienced great economic development evidenced by the construction of numerous public and private buildings, and several settlements corresponding mainly to villae outside the city. The urban function of the city prevailed until the end of Late Antiquity [46,47]. According to archaeological data, the studied site corresponds to a bath complex divided into different rooms, possibly of public use. The chronological sequence of the site is not clear because no archaeological materials susceptible to dating were found. Coatings of stucco, the pictorial elements and stylistic features could point to a relative chronology of about the second century AD.

The excavation at the surrounding settlement of Uxama Argaela allows to study the building technology used outside the urban core. The multi-analytical approach of mortar including macroscopic and microscopic observations, mineralogical and chemical analysis from the different rooms of the studied building will provide information about the manufacturing procedure. To this end, polarised light microscopy, scanning electron microscope, $\mathrm{X}$-ray diffraction and $\mathrm{X}$-ray fluorescence techniques were performed. Since the chronological sequences of rooms are not clear, radiocarbon dating by means of accelerator mass spectrometry on the binder fraction of the mortars were used to establish the chronology of the structure.

The aim of this work is to observe the application of classical construction techniques, to determine the provenance of materials and to estimate the date of building construction. The study will also allow to observe variations on the theoretical Roman technical guidelines.

\section{Materials and Methods}

\subsection{Materials}

The mortars were collected from different rooms in the Roman bath complex. Two mortar samples were collected from floor structures: Sample AD-192 corresponds to a three-layer mortar whereas Sample AD-114 corresponds to a single layer. Six multi-layered plasters from walls of different rooms of the building (Samples AD-132, AD-134, AD-243, AD-058, AD-124 and AD-242) were sampled (Figure 1). Since most samples show multilayer features, the layers were labelled from the outermost layer, L0, corresponding to Layer 0, and successively towards the inside until the innermost layer, L5, corresponding to Layer 5 . In this study, each layer has been considered as a separate sample.

In the absence of an archaeological record to establish the chronology of the building, two wall plasters were analysed in order to determine the age of construction. The three-layer plaster Sample AD-132 could correspond to the original construction phase, whereas the four-layer plaster Sample AD-242 could correspond to a potential modification or improvement of the building. For radiocarbon dating, cocciopesto-free layers were selected, in order to avoid the problems related to hydraulic phases contamination $[28,48-50]$. 

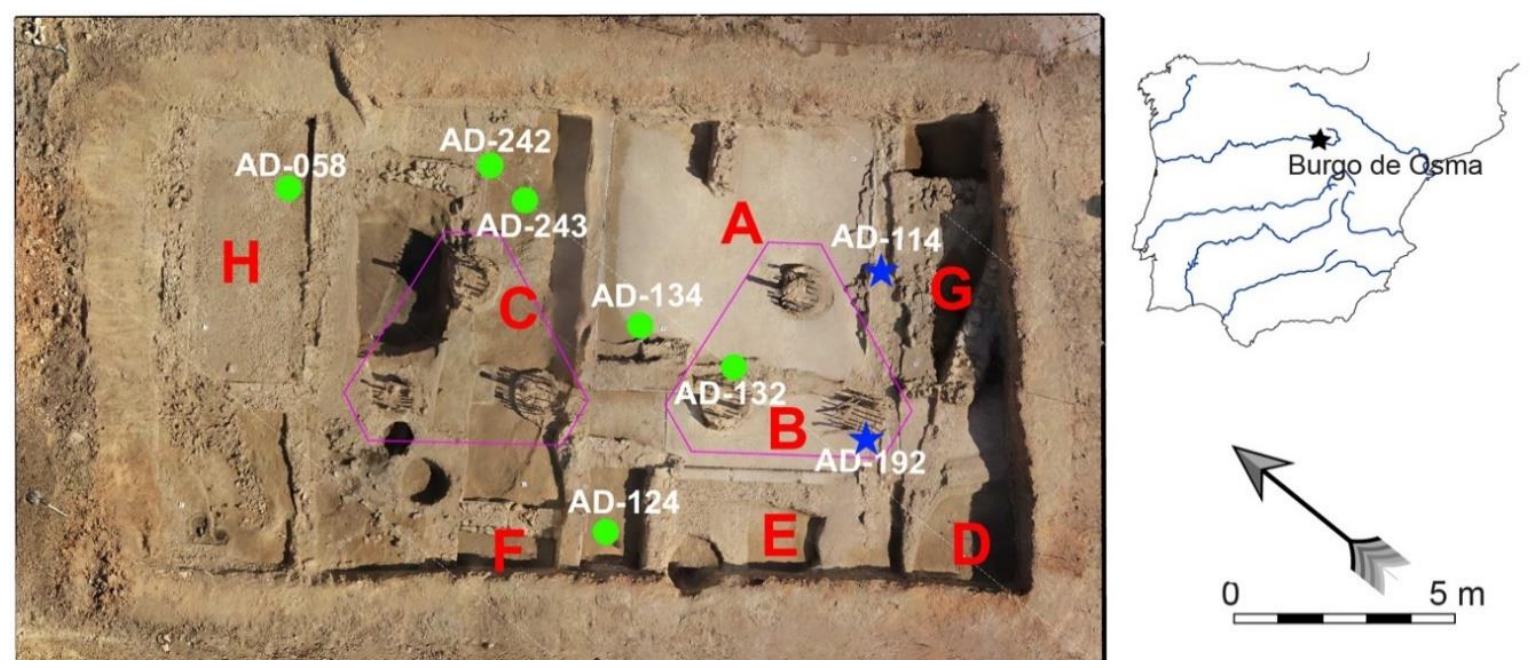

Figure 1. Excavation plan of Arroyo de la Dehesa de Velasco site (Burgo de Osma-Ciudad de Osma, Soria, Spain) and location of the samples in the labelled rooms (A, B, C, D, E, F, G and H). Purple shapes correspond to bridge footings traces of motorway A-11, green circles correspond to wall samples and blue stars to floor samples.

\subsection{Methods}

The entire mortars were extracted parallel to the wall or floor substrate using a water-cooled circular saw. After cleaning, mortar samples were cut perpendicularly to the bedding to observe macroscopic features and the layer profile of the structural mortars, such as colour, thickness, grain shape and size of aggregates.

The mortar component composition, the mineralogy of the binder and the aggregates, grain size and morphological relationships were characterised by petrographic analysis. As thin sections as necessary to complete the total thickness of mortars were obtained. Seventeen thin sections of mortar samples were analysed by Nikon Eclipse LV100pol polarised light microscopy (Nikon, Tokyo, Japan), equipped with a DSF-11 digital camera and a DSL-2 control unit.

A JEOL JSM-6400 Scanning Electron Microscope (SEM) (JEOL, Tokyo, Japan) was used for detailed textural features. Mortar samples were Au-coated to eliminate charging effects. SEM observations were performed in secondary electron (SE) mode.

The mineralogical composition of the coarse binder fraction $(<20 \mu \mathrm{m})$ and the potential neoformed minerals were analysed by X-ray diffraction (XRD). The coarse fraction of the binder was separated by a settling extraction procedure described in Reference [51]. The mortar sample was crumbled up manually and disaggregated in ultrapure water raised up to $\mathrm{pH}=8$ by adding $\mathrm{NH}_{4} \mathrm{OH}$ using an ultrasonic bath, and the suspended fraction was extracted from the topmost supernatant to obtain the $<20$ microns fraction. Mineralogy was determined on a powder sample using a Philips $X^{\prime}$ Pert diffractometer (Malvern PANalytical, Almelo, The Netherlands) equipped with a graphite monochromator adjusted to $\mathrm{Cu}-\mathrm{k} \alpha 1 \mathrm{X}$-radiation operating at $40 \mathrm{kV}$ and $20 \mathrm{~mA}$. The data collection was performed in a continuous scan ranging from $5^{\circ}$ to $70^{\circ} 2 \theta$ at an acquisition rate of $0.02^{\circ} 2 \theta$ per second. The mineral phase identification and semi-quantitative determinations were performed using X'Pert HighScore Plus 3.0 software (Malvern PANalytical).

Major element concentrations of the whole layer samples were determined by wavelength dispersive X-ray fluorescence (WDXRF) using a PANalytical Axios Advanced PW4400 XRF spectrometer (4 kW Rh anode SST-mAX X-ray tube) at the SGIker Facilities. Fused beads were obtained after heating (at $\sim 1200{ }^{\circ} \mathrm{C}$ for $3 \mathrm{~min}$ in Pt/Au crucibles) a mix of $0.2 \mathrm{~g}$ of sample with $3.8 \mathrm{~g}$ of a lithium borate flux (Spectromelt A12, Merck, Kenilworth, NJ, USA) and 2 drops of a lithium bromide solution using a PANalytical Perl'X3 fusion machine. Lower limit of detection for major elements are in the range of $0.01 \mathrm{wt} \%$. The loss on ignition (LOI) was calculated after heating the powder sample at $900{ }^{\circ} \mathrm{C}$. 
The radiocarbon dating of mortar samples was performed on the finer binder fraction corresponding to $0.5-<2 \mu \mathrm{m}$ fraction of a carefully selected layer of multilayer plaster by the ${ }^{14} \mathrm{C}$ accelerator mass spectrometry (AMS) at Beta Analytic Inc. (Miami, FL, USA) and ${ }^{14} \mathrm{C}$ conventional ages were calibrated by OxCal v4.2.3 software [52] and the Intcal13 atmospheric calibration curve [53]. The finest binder fraction was obtained by a settling extraction following the procedure described in References [49,51].

\section{Results and Discussion}

The macroscopic characteristics are summarised in Table 1. The macroscopic characteristics of the floor mortars are different since Sample AD-192 shows a multilayer system whereas AD-114 is a single layer mortar. Mortars from the walls all consist of a multilayer system or multi-layered plasters formed by three to six layers. Samples AD-132, AD-134, AD-243 and AD-058 are formed by three layers and AD-124 and AD-242 by more than five layers (Figure 2).

Table 1. Macroscopic and petrographic characteristics of the mortars.

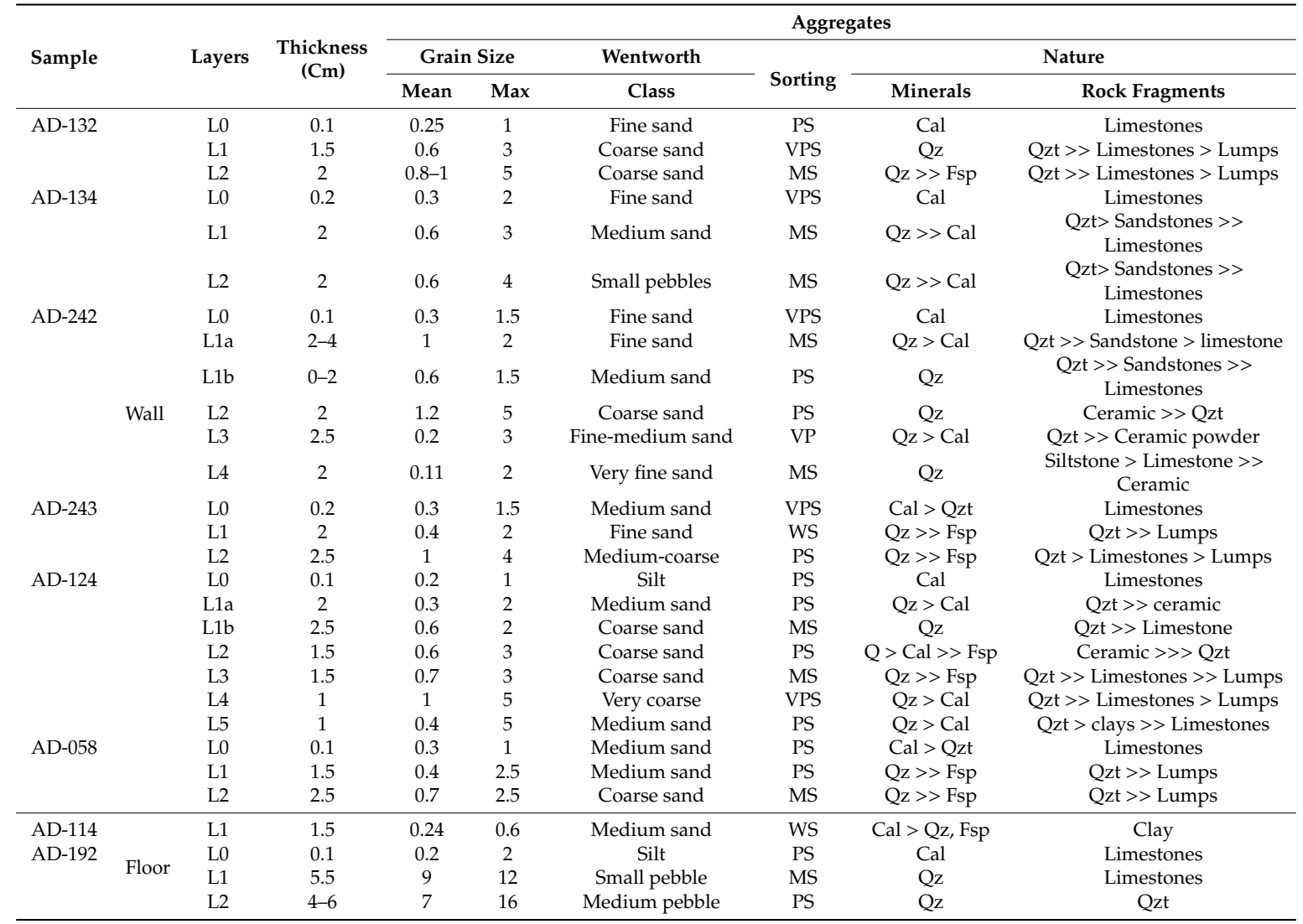

Qz: quartz; Cal: Calcite; Fsp: Feldspar; Qzt: Quartzites; WS: well sorted; MS: medium sorted; PS: poorly sorted; VPS: very poorly sorted.

Wall mortars are composed of a fine light-coloured matrix with coarse-grained rock fragments visible to the naked eye as aggregates. Rock fragments are mainly sub-rounded in shape, of variable colour, from milky to yellow-orange-brown, and composed mainly of siliceous detrital sands (quartz and quartzites) and a minor amount of subangular limestones and sandstones. Voids are common both parallel to the layers and randomly oriented, probably formed by the dissolution of grass stalks. The binder is light in colour from creamy to orangish, and white lumps or scarcely mixed lime inclusions [54-56] are abundant, ranging from macroscopic to microscopic scale. Vegetable fibre remains, probably straw, are observed in most mortars, particularly in the inner layers. In most cases, 
cohesion and adhesion of layers in the mortars is excellent. Only two wall mortars show reddish-pinkish layers due to the occurrence of ceramic fragments and/or powder, known as cocciopesto.
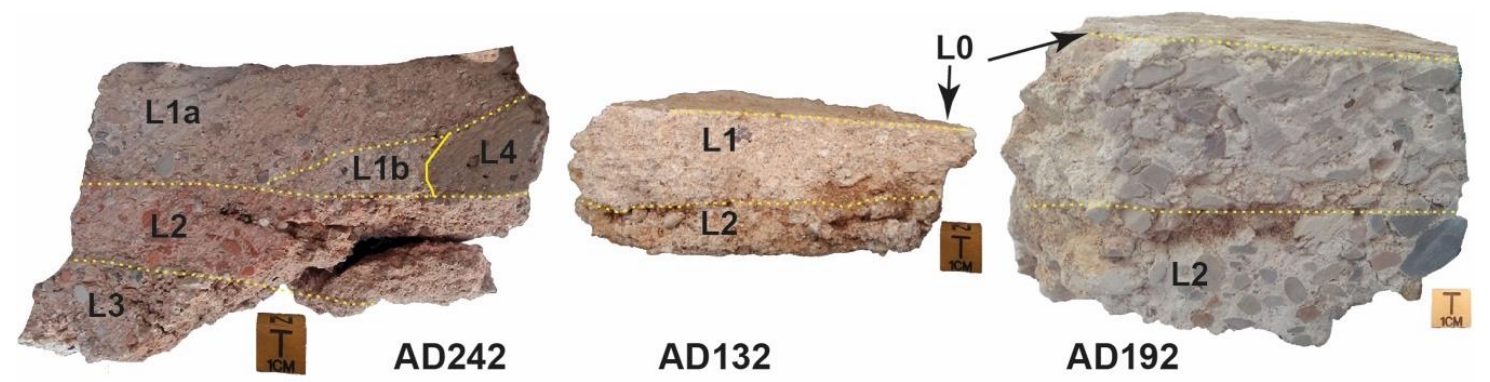

Figure 2. Representative samples of mortars from the Arroyo de la Dehesa de Velasco site. Sample AD-242: Multilayer wall plaster with cocciopesto layer. Sample AD-132: Two layers of wall siliceous plaster with an outermost marmorino layer. Sample AD-192: Multilayer floor mortar with three layers, L0 marmorino layer, L1 crushed limestone and L3 siliceous pebbles with calcite binder.

All wall plasters display an outermost, very-thin whitish pictorial layer (1-2 mm) known as the marmorino layer (L0) [40,57-59]. Towards the inside, two layers (L1, L2) can be distinguished composed of sandy siliceous aggregates of whitish-greyish colour in a calcitic binder. Each layer 2 $\mathrm{cm}$ in thickness contains homogeneous grain-size aggregates, and both layers have similar aggregate compositions differing in aggregate sorting. The outermost layer (L1) displays a fine grain size, whereas the innermost layer (L2) shows a coarse grain size. Samples AD-124 and AD-242 consist of six and five layers respectively, and are characterised by reddish-pinkish layers enriched in crushed ceramic materials intentionally added. Besides, these mortars show a clayey brownish scratch coat layer in contact with the wall substrate or a joining coat composed of subangular quartz and feldspars with scarce lime lumps.

The two floor mortar samples are quite different: Sample AD-192 corresponds to a multilayer system consisting of three layers with a light-coloured matrix. The outermost layer (L0) is a marmorino-like layer. The upper layer (L1) consist of aggregates of crushed limestone, homogeneous in grain size, whereas the inner layer (L2) shows rounded siliceous pebbles of more heterometric grain size (Figure 2). Layer L2 additionally contains moulds of the large pebbles probably used in the statumen or a preparatory bottom layer formed of pebbles in order to stabilize the ground [40,57-59]. Sample AD-114 is characterised by only one sandy-clayey brownish layer with rounded aggregates of siliceous nature and sand-grain size.

The petrographic analysis is able to characterise the aggregate mineral composition and the binder features (Table 1) [60]. Wall plaster aggregates possess a grain size ranging from fine to coarse sand, according the classification in Reference [61], and subangular to subrounded shape [62]. Their nature corresponds to quartz, with a minor amount of potassium feldspar, and the rock fragments are mainly quartzite, limestones and arenites. Quartz and quartzites generally possess a high sphericity index and subrounded shapes, whereas limestone and sandstone fragments are subangular with low sphericity. Three-layer wall plasters show grain size grading of aggregates from coarse grain size in the inner layer, L2, to fine grain size in the outer layer, L1. Besides, each layer shows a distinctive sorting leading to layering. Vegetable fibre remains are usually observed in some layers, mainly in the inner layers. Multilayer wall mortars show mainly similar features related to grain size distribution (Figure 3). In contrast, distinctive aggregate sorting patterns are observed in each layer, varying between poorly to moderately sorted $[63,64]$. The ceramic fragments in the cocciopesto layer are poorly sorted showing angular shapes and low sphericity and sometimes showing reaction rims. The outermost marmorino layer shows angular carbonate aggregates embedded in a micritic matrix with an aggregate/binder ratio of $<1$ or nearly 1 (Figure 3 ). The innermost clayey mortars corresponding to the scratch coats or joining coats differ from the other wall mortar layers in the aggregate nature and grain size distribution. This 
layer is characterised by a high density of low-roundness quartz and potassium feldspar aggregates of homogeneous grain size showing an aggregate/binder ratio of $>1$.
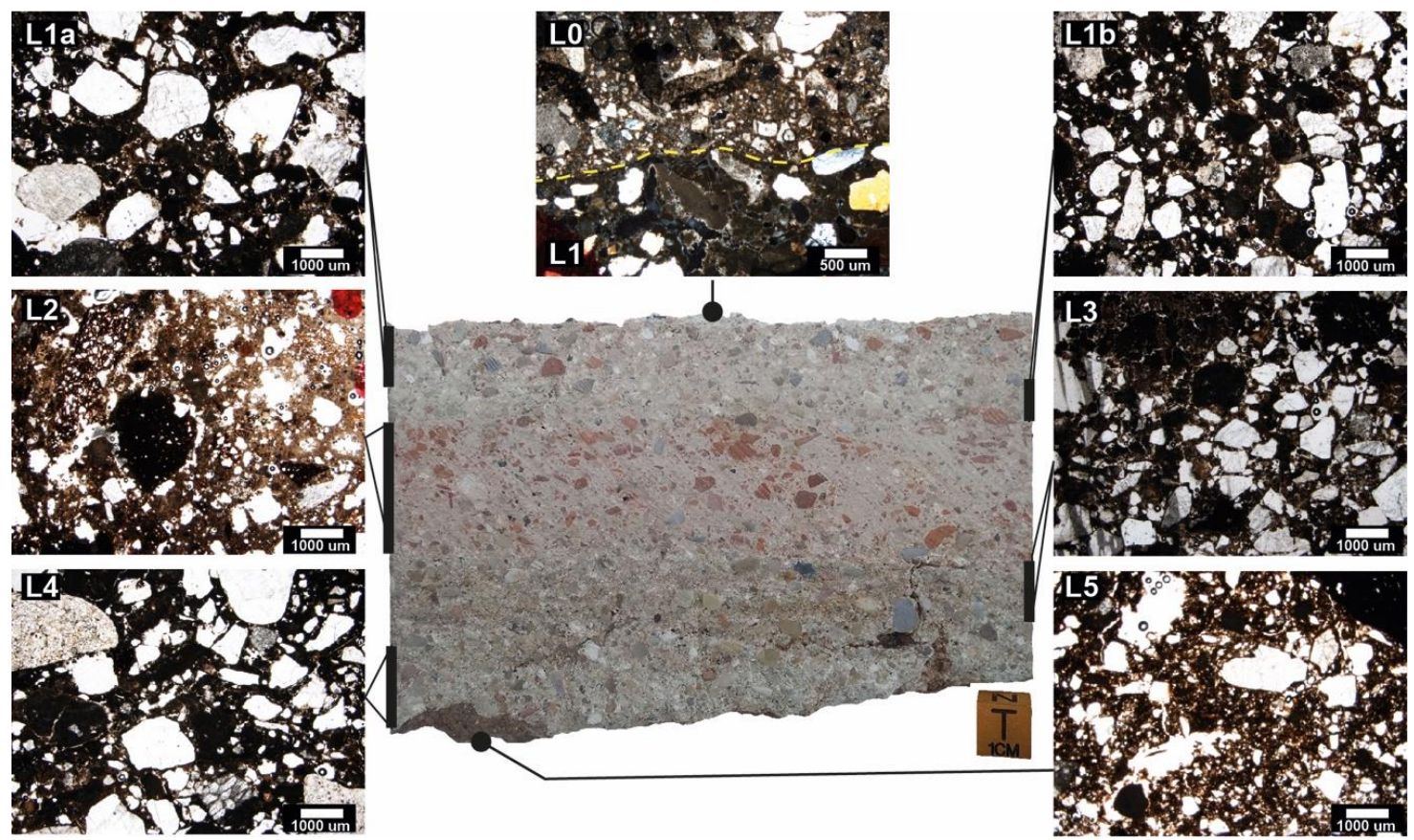

Figure 3. Photomicrographs of the different layers (L0-L6) in the AD-124 wall mortar.

Floor mortars are different since Sample AD-114 has a single layer and Sample AD-192 has a multilayer system of three layers. The floor AD-114 shows a homogeneous medium-grain size of subangular quartz aggregates in a matrix composed of a mixture of lime and clay with an aggregate/binder ratio of $>1$. Sample AD-192 shows a clear grading upwards from medium-pebble grain size in the innermost layer to silt in the marmorino layer. The layers contain aggregates of different nature. The innermost layer, L2, is composed of centimetric very rounded quartz and quartzite rock fragments, whereas layer L1 is formed by centimetric angular limestone fragments of heterogeneous origin, such as nodulous limestones, miliolid limestones, bioclastic mudstones and recrystallised limestones [60] The outermost marmorino layer shows angular carbonate aggregates embedded in a micritic matrix.

The multilayer system in the walls and in the floors was created according to the building methods documented by Vitruvius [40] and used in numerous Roman sites. The mortar technology usually consisted of two or three layers under the pictorial layer promoting a suitable support for wall paintings. The wall mortars were composed of a mixture of lime and sands, with an aggregate/binder ratio of 2:1 or 3:1, with a slight increase in binder content towards the outside. The cocciopesto layers were probably manufactured to confer hydraulicity to mortars, improving the strength and moisture resistance [65-67]. Similar technology was used for floor substrates, which were manufactured according to recipes described by ancient authors [40,41]. Floor mortars consist of an inner layer formed by a mixture of natural aggregates and binder with an aggregate/binder ratio of $>1$ and an upper layer consisting of a mixture of crushed coarse limestone aggregates and binder, with an aggregate/binder ratio of $<1$. No crushed bricks were used in the floor layering. Both wall and floor structures were finished with a thin lime, with a euhedral calcite or limestone fragments layer or a marmorino layer (Figure 3). The microtextural feature of the marmorino layer can be observed in detail by SEM, revealing a microcrystalline calcite (Figure 4A). SEM analyses also allow the observation of some vegetal ghosts since druse habit calcium carbonate is formed, covering the pre-existing vegetal remains (Figure 4B). 

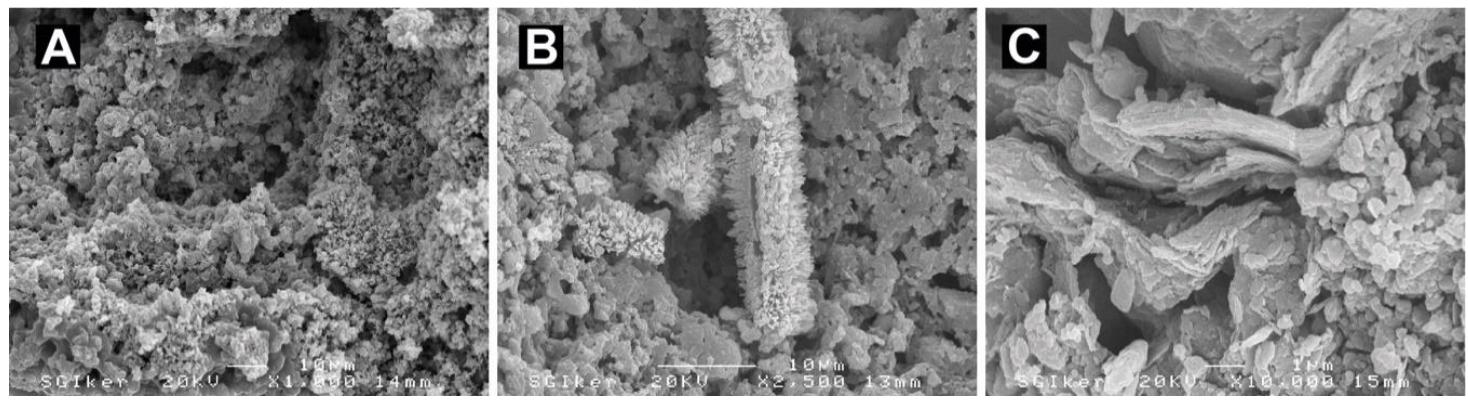

Figure 4. Scanning electron microscope (SEM) images of: (A) bulk calcite of the marmorino layer, (B) calcite growing on a vegetable fibre, and (C) laminar kaolinite mineral among the calcite binder.

Multilayer systems are common in important buildings and were a common practice in ancient Roman territories [59,68-70], applied under pictorial-bearing walls and on floor substrates to promote their durability and conservation [71,72]. Although very little remains of the building have been found, the use of these constructive techniques indicates the social and/or economic significance of the Arroyo de la Dehesa de Velasco site.

Table 2 summarises the XRD mineralogical composition of the coarse fraction $(<20 \mu \mathrm{m})$ of the mortar binder. The binder fraction is composed mainly of calcite and, in minor amounts, phyllosilicates and quartz. Clay minerals are represented by kaolinite and illite. SEM images show a planar-habit slightly-folded kaolinite-like mineral (Figures $4 \mathrm{C}$ and 5). The lack of clay minerals in some samples does not mean that they are totally absent but that they may be under the detection limit.

Table 2. X-ray diffraction (XRD) mineralogical composition of the coarse fraction of mortar binder.

\begin{tabular}{|c|c|c|c|c|c|}
\hline Sample & & Calcite & Phyllosilicates & Quartz & $\mathrm{K} \ln / \mathrm{Ilt}$ \\
\hline AD-132 & \multirow{13}{*}{ Wall } & 99 & 0 & 1 & - \\
\hline AD-134 & & 98 & 0 & 2 & - \\
\hline AD-242-L1 & & 99 & 0 & 1 & - \\
\hline AD-242-L2 & & 59 & 36 & 5 & $13 / 23$ \\
\hline AD-242-L3 & & 68 & 31 & 1 & $28 / 3$ \\
\hline AD-243 & & 99 & 0 & 1 & - \\
\hline AD-124-L0 & & 76 & 18 & 6 & $9 / 9$ \\
\hline AD-124-L1 & & 81 & 18 & 1 & $9 / 9$ \\
\hline AD-124-L2 & & 80 & 16 & 4 & $0 / 16$ \\
\hline AD-124-L3 & & 82 & 15 & 3 & $4 / 11$ \\
\hline AD-124-L4 & & 98 & 0 & 2 & - \\
\hline AD-124-L5 & & 85 & 13 & 2 & $6 / 7$ \\
\hline AD-058 & & 77 & 23 & 1 & $17 / 6$ \\
\hline AD-114 & \multirow{3}{*}{ Floor } & 76 & 20 & 4 & $11 / 9$ \\
\hline AD-192-L1 & & 99 & 0 & 1 & - \\
\hline AD-192-L2 & & 99 & 0 & 1 & - \\
\hline
\end{tabular}

In bold lettering: cocciopesto layer. Kln: kaolinite, Ilt: illite, - not detected. Values in relative percentages.

The mineralogy of floor mortar binder agrees with the petrological study. Single layer sample AD-114 shows a large amount of phyllosilicates composed of a mixture of illite and kaolinite minerals according to the sandy-clayey nature of the mortar (Table 2). In contrast, the binder of Sample AD-192 is formed by calcite. For the three-layer wall mortars, only one whole sample has been analysed by XRD because layering is attributable to grain size distribution, as the petrographic study has revealed. Among the three-layer samples, the binder of AD-058 stands out because of its high phyllosilicate content, mainly kaolinite, whereas the binders of the other samples are only formed by calcite. The multilayer wall mortars AD-124 and AD-242 also show a large amount of phyllosilicates. In most layers, kaolinite is more abundant than illite, and illite is more abundant than kaolinite only in cocciopesto 
layers. The large amount of illite in cocciopesto layers is because of the intentionally added ceramic fragments. The occurrence of kaolinite in multilayer mortars with cocciopesto layers can suggest intentionality in mortar manufacture.

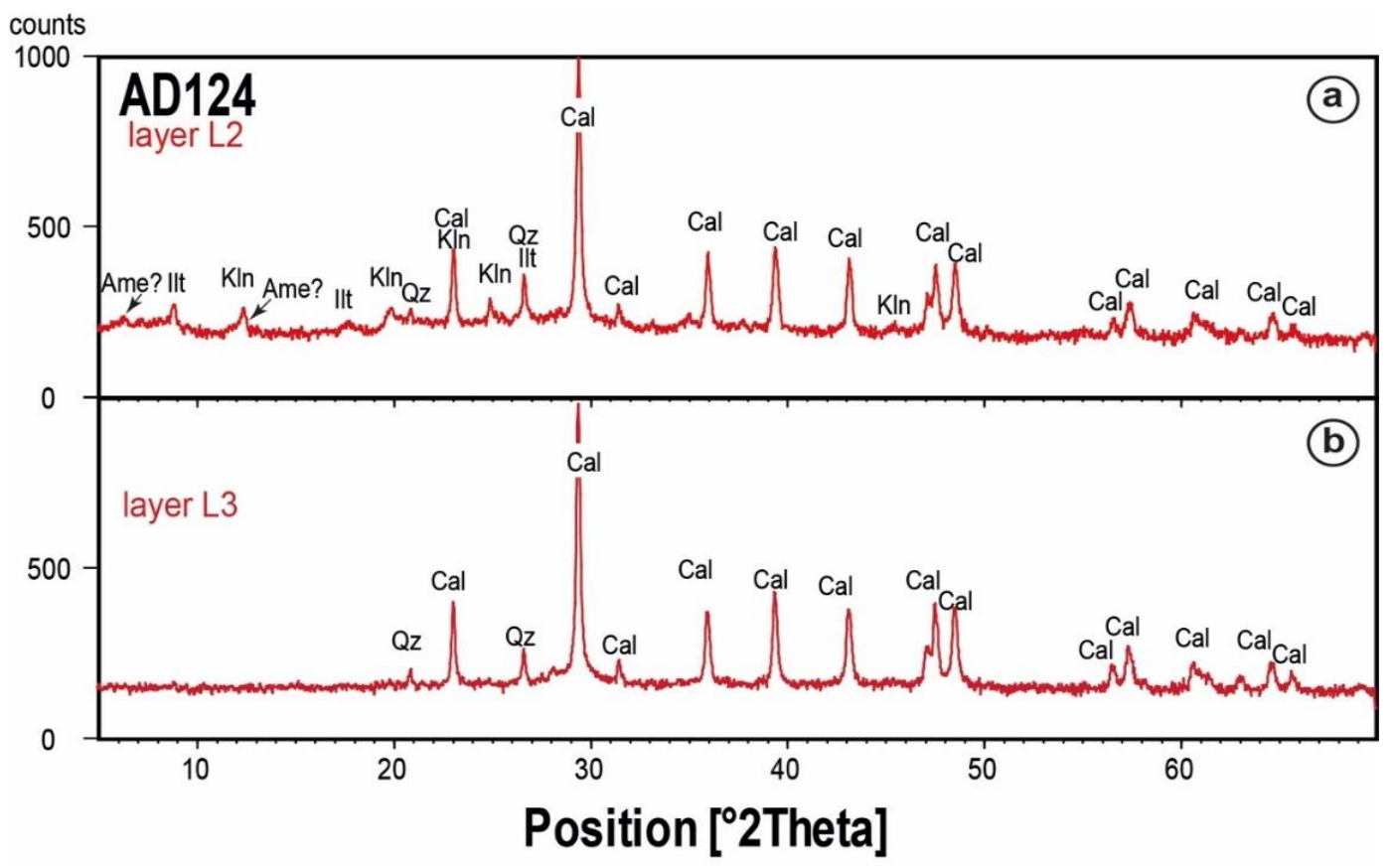

Figure 5. Representative XRD patterns of the AD-124 mortar binder: (a) XRD pattern of binder from layer L2 with ceramic fragments, (b) XRD pattern of binder from layer L3 without ceramic fragments. (Cal: calcite, Qz: quartz, Kln: kaolinite, Ill: illite, Ame: amesite).

Crushed ceramics were added to confer hydraulic properties to non-hydraulic mortars. The reaction rim surrounding the crushed ceramics suggests the occurrence of aluminosilicate hydrated products formed by the reaction aluminosilicate phases in the presence of water with the calcium hydroxide. Although, hydraulic newformed phases were not easy to identify by XRD due to their low crystallinity and low concentration in the binder [73-75]. However, in the binder of cocciopesto layers, reflections at $7.03 \AA$ and $3.51 \AA$ can be attributed to amesite $\left(\mathrm{Mg}_{2} \mathrm{Al}_{2} \mathrm{SiO}_{5}(\mathrm{OH})_{4}\right)$, which is a magnesium aluminosilicate hydrate phase (M-A-S-H) (Figure 5a). On the contrary, these reflections are not observed in the binder of layers without ceramic fragments, where only calcite and quartz were identified (Figure 5b).

Cocciopesto mortars have often been used for waterproofing cisterns and waterways $[6,66,75,76]$. The composite mortar made by packing cocciopesto-bearing and cocciopesto-free layers not only confer resistance to the moisture but also improve the mechanical properties and stability of mortars $[67,77]$.

The chemical composition of all the mortar samples is detailed in Table 3 . The chemical composition is related to the composition of aggregates and binder. Mortars show a high content of silica, ranging from $43 \mathrm{wt} \%$ to $64 \mathrm{wt} \%$, and of lime, ranging from $16 \mathrm{wt} \%$ to $27 \mathrm{wt} \%$, according to the siliceous aggregate and binder nature, respectively. $\mathrm{Al}_{2} \mathrm{O}_{3}$ ranges between $0.8 \mathrm{wt} \%$ and $8.8 \mathrm{wt} \%, \mathrm{Fe}_{2} \mathrm{O}_{3} \mathrm{t}$ between $0.2 \mathrm{wt} \%$ and $2.8 \mathrm{wt} \%$ and $\mathrm{K}_{2} \mathrm{O}$ between $0.3 \mathrm{wt} \%$ and $1.6 \mathrm{wt} \%$.

Cocciopesto layers in the multilayer AD-124 and AD-242 mortars display the highest values of aluminum, iron, potassium and titanium, owing to the occurrence of ceramic and tile fragments. However, other layers in these samples also display relatively high contents of these elements, suggesting the presence of ceramic powder in the mortar. Kaolinite-rich sample AD-058 does not show high aluminum values, suggesting that the mineralogical contents determined by XRD are significantly over-quantified. The two multilayer mortars are quite different in their chemical composition, and the higher calcium content of the AD-124-1 layer is because of the lump abundance. 
Table 3. Major element chemical composition of mortars by X-ray fluorescence (XRF) analysis (in wt $\%$ ).

\begin{tabular}{ccccccccccccc}
\hline Sample & $\mathbf{S i O}_{2}$ & $\mathbf{A l}_{\mathbf{2}} \mathbf{O}_{\mathbf{3}}$ & $\mathbf{F e}_{\mathbf{2}} \mathbf{O}_{\mathbf{3}} \mathbf{t}$ & $\mathbf{M n O}$ & $\mathbf{M g O}$ & $\mathbf{C a O}$ & $\mathbf{N a}_{\mathbf{2}} \mathbf{O}$ & $\mathbf{K}_{\mathbf{2}} \mathbf{O}$ & $\mathbf{T i O}_{2}$ & $\mathbf{P}_{2} \mathbf{O}_{5}$ & $\mathbf{S O}_{3}$ & $\mathbf{L O I}$ \\
\hline AD-132 & 52.97 & 0.87 & 0.31 & 0.01 & 0.13 & 22.12 & 0.00 & 0.32 & 0.07 & 0.04 & 0.04 & 22.90 \\
$\mathrm{AD}-134$ & 58.54 & 0.97 & 0.38 & 0.02 & 0.24 & 19.17 & 0.01 & 0.32 & 0.07 & 0.07 & 0.02 & 19.11 \\
$\mathrm{AD}-242-1$ & 52.58 & 0.82 & 0.20 & 0.01 & 0.16 & 22.47 & 0.00 & 0.36 & 0.06 & 0.06 & 0.13 & 22.40 \\
$\mathrm{AD}-242-2$ & 45.06 & 8.79 & 2.75 & 0.03 & 0.56 & 19.55 & 0.04 & 1.58 & 0.40 & 0.16 & 0.21 & 20.09 \\
$\mathrm{AD}-242-3$ & 43.35 & 3.09 & 0.86 & 0.01 & 0.49 & 24.81 & 0.03 & 0.50 & 0.13 & 0.08 & 0.14 & 25.09 \\
$\mathrm{AD}-242-4$ & 44.64 & 4.63 & 1.38 & 0.03 & 0.32 & 23.13 & 0.04 & 1.09 & 0.26 & 0.18 & 0.07 & 22.66 \\
$\mathrm{AD}-243-1$ & 61.31 & 0.88 & 0.24 & 0.01 & 0.26 & 17.49 & 0.00 & 0.39 & 0.06 & 0.05 & 0.02 & 18.92 \\
$\mathrm{AD}-243-2$ & 64.29 & 0.92 & 0.25 & 0.01 & 0.21 & 16.21 & 0.00 & 0.43 & 0.08 & 0.04 & 0.02 & 17.26 \\
$\mathrm{AD}-124-1$ & 42.37 & 1.65 & 0.58 & 0.01 & 0.25 & 26.77 & 0.01 & 0.42 & 0.09 & 0.04 & 0.07 & 26.59 \\
$\mathrm{AD}-124-2$ & 39.58 & 7.39 & 2.28 & 0.02 & 0.46 & 23.44 & 0.04 & 1.30 & 0.33 & 0.10 & 0.20 & 24.06 \\
$\mathrm{AD}-124-3$ & 55.17 & 0.98 & 0.28 & 0.01 & 0.24 & 20.35 & 0.01 & 0.32 & 0.06 & 0.03 & 0.04 & 21.68 \\
$\mathrm{AD}-124-4$ & 50.41 & 0.87 & 0.28 & 0.01 & 0.21 & 23.06 & 0.00 & 0.30 & 0.07 & 0.03 & 0.03 & 23.61 \\
$\mathrm{AD}-124-5$ & 49.94 & 3.02 & 0.94 & 0.02 & 0.31 & 20.42 & 0.05 & 0.79 & 0.20 & 0.07 & 0.03 & 22.78 \\
$\mathrm{AD}-058$ & 59.07 & 0.81 & 0.43 & 0.01 & 0.13 & 19.62 & 0.00 & 0.32 & 0.05 & 0.07 & 0.02 & 19.25 \\
$\mathrm{AD}-114$ & 62.00 & 1.81 & 0.40 & 0.01 & 0.22 & 16.87 & 0.00 & 0.87 & 0.13 & 0.07 & 0.06 & 15.93 \\
\hline
\end{tabular}

$\mathrm{Fe}_{2} \mathrm{O}_{3}$ t: Total iron reported as $\mathrm{Fe}_{2} \mathrm{O}_{3}$. LOI: Loss on ignition.

The compositional variation of mortars is plotted in binary diagrams (Figure 6). Diagrams of $\mathrm{CaO} / \mathrm{Al}_{2} \mathrm{O}_{3}$ ratio versus oxides allow to distinguish two groups of samples. The group with low $\mathrm{CaO} / \mathrm{Al}_{2} \mathrm{O}_{3}$ ratio shows high contents of iron and potassium and low silica content corresponding to clay-rich mortars and cocciopesto mortars, and the group with high $\mathrm{CaO} / \mathrm{Al}_{2} \mathrm{O}_{3}$ ratio displays low iron and potassium contents, and a high content in silica corresponding to siliceous sandy mortars. The $\mathrm{CaO}$ content can be related with the variable amount of lumps in some layers. Nevertheless, the lime content is similar in both groups and is not a distinctive chemical feature. Thus, geochemical differences accord with the mineralogical features of the mortars.

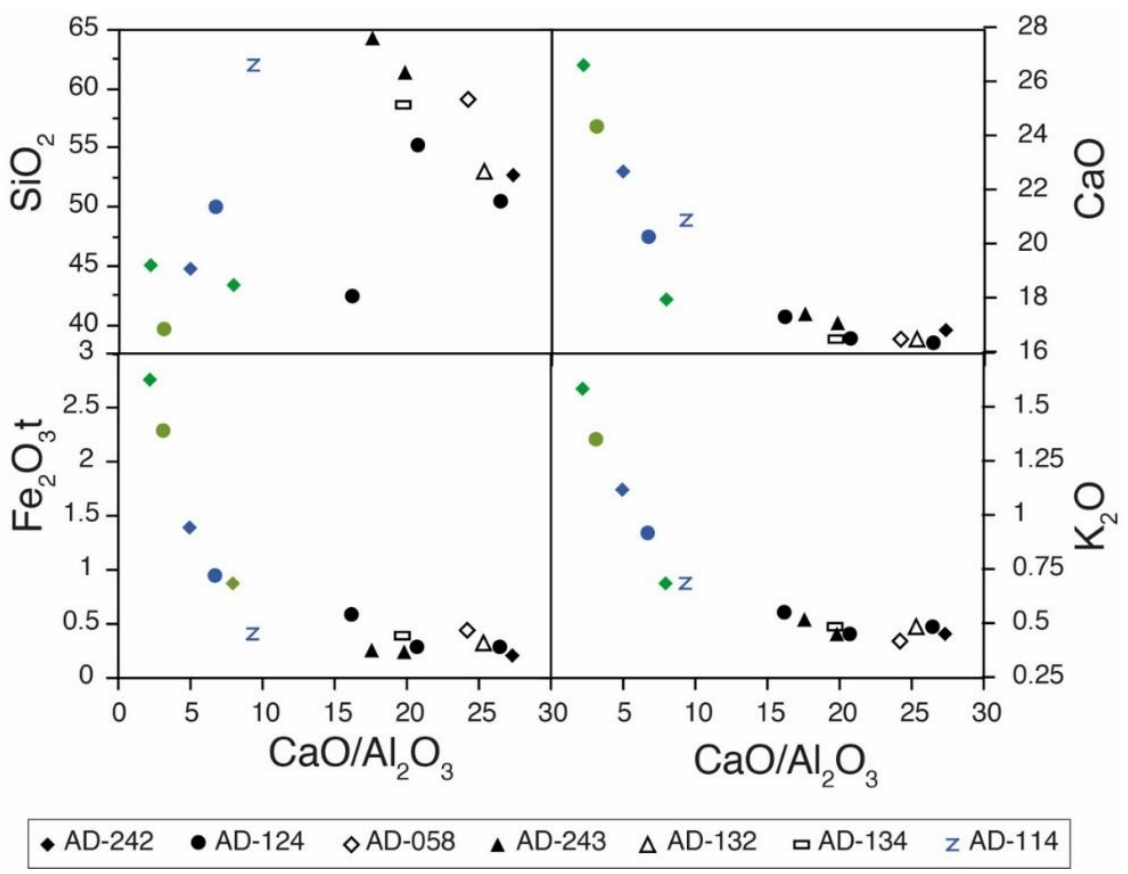

Figure 6. Binary diagrams of $\mathrm{CaO} / \mathrm{Al}_{2} \mathrm{O}_{3}$ versus $\mathrm{SiO}_{2}, \mathrm{CaO}, \mathrm{Fe}_{2} \mathrm{O}_{3}$ and $\mathrm{K}_{2} \mathrm{O}$ oxides plotting the chemical composition of Arroyo de la Dehesa de Velasco site mortar layers. Green symbols correspond to layers with ceramic fragments. Blue symbols correspond to clay-rich scratch coat layers from plasters and to sandy-clayey floor mortar. 
Hierarchical clustering analysis on the basis of chemical data discriminates two main clusters of mortars (Figure 7). The first cluster groups AD-124-2, AD-242-2, AD-242-4, AD-242-3 and AD-124-5 samples enriched in $\mathrm{Al}_{2} \mathrm{O}_{3}, \mathrm{TiO}_{2}, \mathrm{Fe}_{2} \mathrm{O}_{3}, \mathrm{MgO}$ and $\mathrm{K}_{2} \mathrm{O}$ corresponding to layers with ceramic fragments and to clay-rich scratch layers. Two sub-clusters can be distinguished, one including layers AD-124-2 and AD-242-2 related to ceramic-rich aggregate layers, and the other including AD-242-4, AD-124-5 clay-rich layers and the AD-242-3 layer with a ceramic powder-rich layer. The second cluster includes Samples AD-058, AD-134, AD-114, AD-243-1, AD-243-2, AD-132, AD-124-1, AD-124-3, AD-124-4 and AD-242-1 corresponding to three-layer siliceous mortars, to the innermost siliceous layer of the floor mortar and clay-free layers of multilayer mortars. Additionally, two sub-clusters can be distinguished, one group displays high $\mathrm{SiO}_{2}$ and low $\mathrm{CaO}$ contents (AD-058, AD-134, AD-114, AD-243-1 and $\mathrm{AD}-243-2$ layers), and the second group shows higher $\mathrm{CaO}$ and lower silica content related to the large amount of carbonate-nature aggregates and lime lumps (AD-124-1, AD-124-3, AD-124-4, AD-132 and AD-242-1 layers).

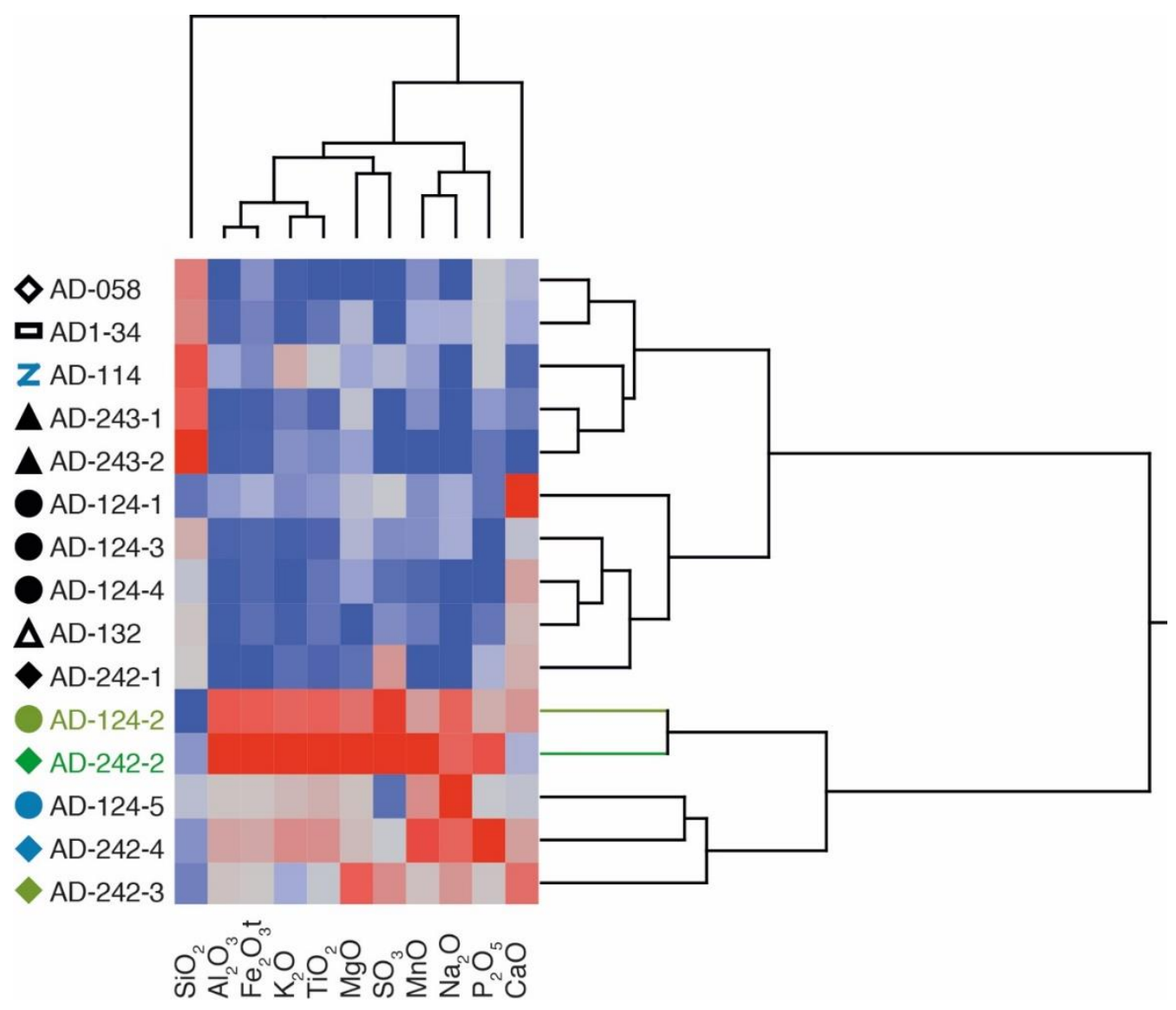

Figure 7. Dendrogram of the mortars according to their layers. Green symbols correspond to layers with ceramic fragments. Blue symbols correspond to clay-rich layers and sandy-clayey layer.

According to the mineralogical and petrographic results, raw material typology and provenance issues can be resolved. Siliceous sands, limestones and ceramic fragments were mainly used for the mortar. Various Cretaceous limestones outcropping near Uxama Argaela (Burgo de Osma-Ciudad de Osma) were probably the source for the production of lime. Moreover, limestone aggregates used for the floor mortars, corresponding to bioclastic limestone with miliolid fragments, indicates that Hortezuelos and Hontoria del Pinar limestones located to the south of Burgo de Osma could be the provenance area (Figure 8). Siliceous nature aggregates are the other important materials in the mixture. These correspond to sands composed mainly of rounded quartz and quartzites. The source of 
such sands can be ascribed to Cenozoic detrital materials, which are very abundant around the site. However, the exact raw material provenance is difficult to establish because of the monotony of facies, scarcity of fossil record and the lack of outcrop continuity. Besides, Quaternary fluvial materials from the Abión River, which are mostly composed of quartz and quartzites, could also be used as aggregates in the mortar manufacture. The lack of particular markers makes it difficult to fix the provenance area because lithologies of different ages are mainly composed of similar detrital mineral phases. Nevertheless, the occurrence of kaolinite allows the provenance of these aggregates to be determined. Kaolinite-bearing detrital materials of Oligocene age were described near the site [78], pointing to these materials as the probable provenance for the aggregates. Thus, of the materials used to elaborate the wall plasters and floor mortars, both lime and aggregates came from the surrounding geological materials. The use of local materials and the multi-layered manufacture follow the guidelines described by Vitruvius.

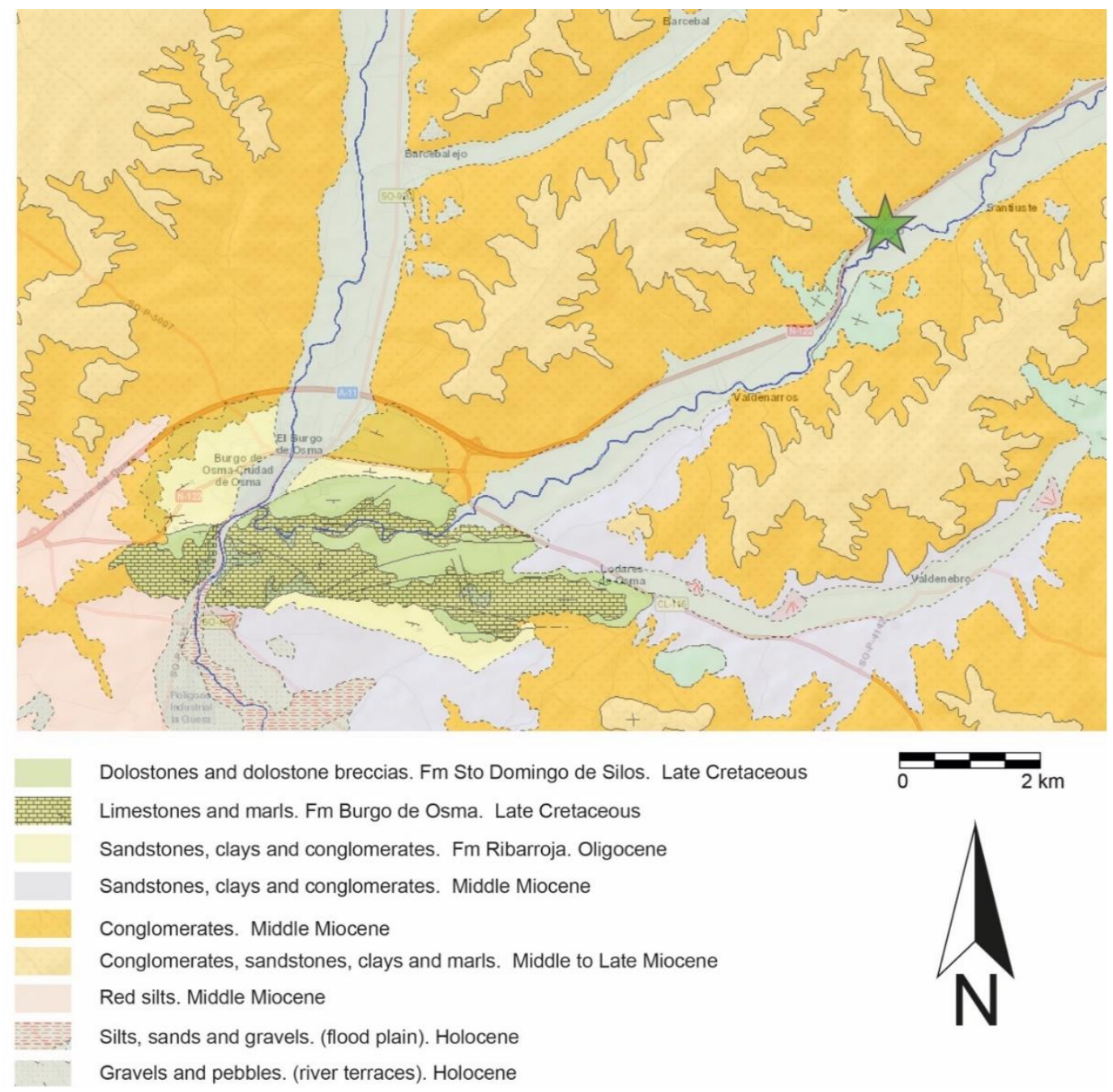

Figure 8. Geological map and location of the Arroyo de La Dehesa de Velasco site (star).

The lack of written sources and archaeological evidence at Arroyo de La Dehesa de Velasco mean that the date of the building complex is unknown. According to archaeological criteria, two samples were selected for radiocarbon dating, Sample AD-132 from Room A, corresponding to the original constructive mortar, and Sample AD-242 from Room C, corresponding to an improvement of the building. Sample AD-242 presents layers with cocciopesto, but these layers have been avoided since 
dating mortars with cocciopesto can be problematic, especially due to some neoformation minerals that can interfere $[48,49]$.

Binder fraction between 0.5 and $<2 \mu \mathrm{m}$ of two mortar samples was extracted for radiocarbon dating following the procedures described in References [49,51]. The siliceous L2 layer of Sample AD-132 and the L1 layer of Sample AD-242 were selected to obtain the suitable binder fraction. Prior to dating, the binder fraction XRD was performed to assure the suitability of the selected fraction (Figure 9). Traces of phyllosilicates leading to contamination are concentrated in the $>2 \mu \mathrm{m}$ and $<0.5 \mu \mathrm{m}$ grain-size fractions (Figure $9 \mathrm{a}, \mathrm{c}$ ). The $0.5-2 \mu \mathrm{m}$ fraction does not show these potential contaminants; therefore, this binder fraction was selected for dating (Figure 9b).

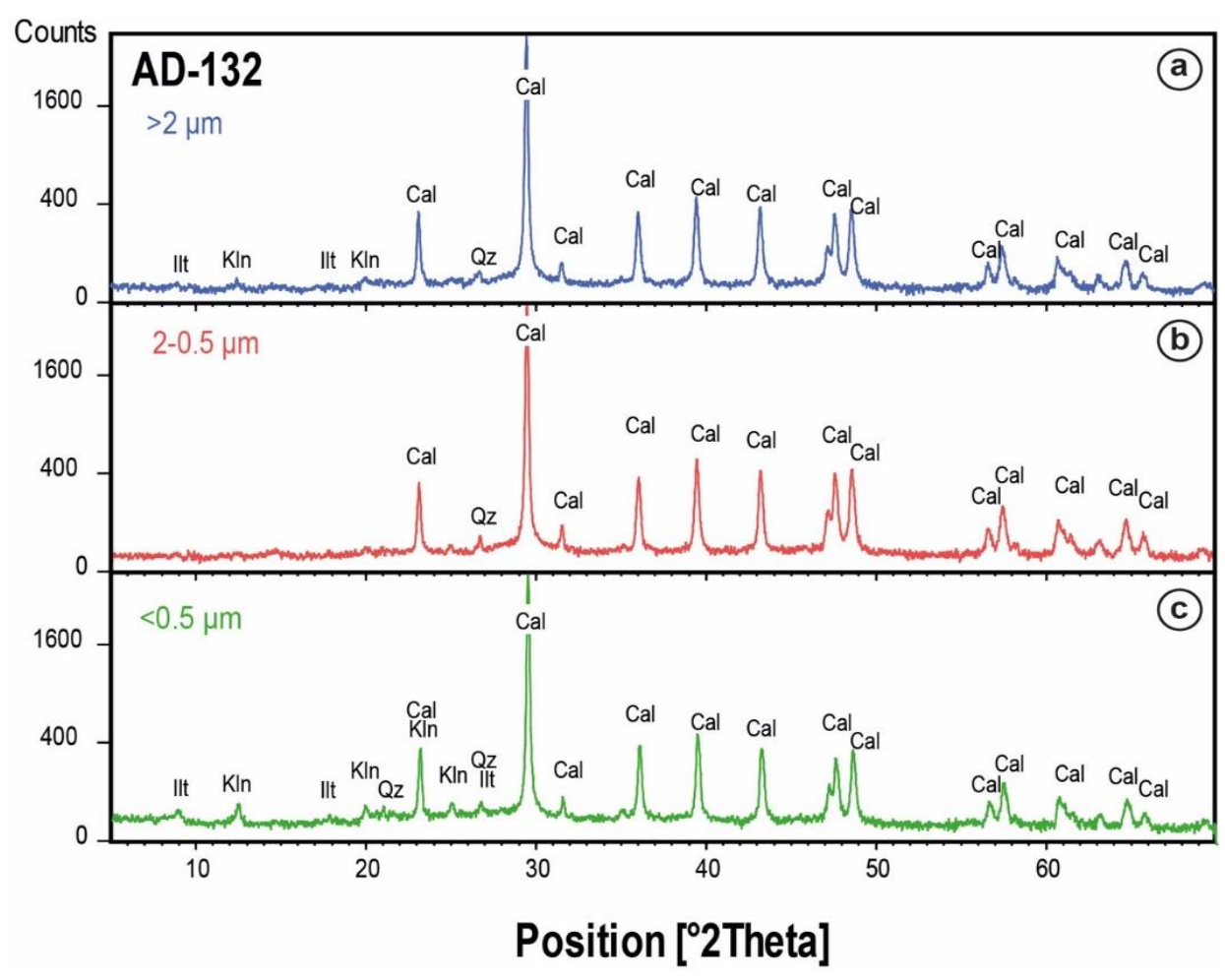

Figure 9. XRD patterns of extracted binder fractions of Layer L2 of Sample AD-132: (a) XRD pattern of $>2 \mu \mathrm{m}$ fraction, (b) XRD pattern of 0.5-2 $\mu \mathrm{m}$ corresponding to the datable fraction and (c) XRD pattern of $<0.5 \mu \mathrm{m}$ fraction.

The result of ${ }^{14} \mathrm{C}$ dating of the AD-242 sample is $2120 \pm 30 \mathrm{BP}$ corresponding to the calendar age of 206-50 BC (Table 4, Figure 10A) and for the AD-132 sample is $2130 \pm 30 \mathrm{BP}$ corresponding to the calendar age of 210-52 BC (Figure 10B). Archaeological remains indicating occupation date of the site are very scarce, but several historical milestones allow to limit the range of building age. According to the historical sources, the Romanisation of the region could not begin until after the conquest of Numantia in 133 BC. Besides, Uxama Argaela was burned down in 72 BC by Pompey for supporting Sertorius during the first republican civil war. Both historical milestones limit the oldest age of building age to ca $70 \mathrm{BC}$. Among the scarce archaeological remains, some fragments of terra sigillata dated between 40-80 AD corresponding to abandonment of the building indicate that the construction of the building must indubitably be earlier. In summary, according to historical data, the age of the building must be before $40 \mathrm{AD}$ (age of abandonment) and later to $133 \mathrm{BC}$, corresponding to the beginning of the Romanisation on the region. Considering a bayesian approach, the most probable age of construction would be before $50 \mathrm{BC}$. Both the original construction (sample AD-132) and improvement (sample AD-242) dates of the building are close, suggesting that the bath complex of Arroyo de La Dehesa de Velasco was built during the first century BC. 
Table 4. Radiocarbon age determinations of the mortars from Arroyo de La Dehesa de Velasco.

\begin{tabular}{ccccc}
\hline Lab Code & Sample & Conventional Age & $\boldsymbol{\delta}^{\mathbf{1 3}} \mathbf{C}$ & $\begin{array}{c}\text { Calibrated Age } \\
\text { Ranges (2 } \mathbf{\sigma})\end{array}$ \\
\hline Beta-511088 & AD-242 & $2120+/-30 \mathrm{BP}$ & $-14.3 \%$ & $206-50 \mathrm{BC}(91.2 \%)$ \\
Beta-511089 & AD-132 & $2130+/-30 \mathrm{BP}$ & $-14.4 \%$ & $345-322 \mathrm{BC}(4.2 \%)$ \\
& & & $210-52 \mathrm{BC}(84.9 \%)$ \\
& & & $350-308 \mathrm{BC}(10.5 \%)$ \\
\hline
\end{tabular}
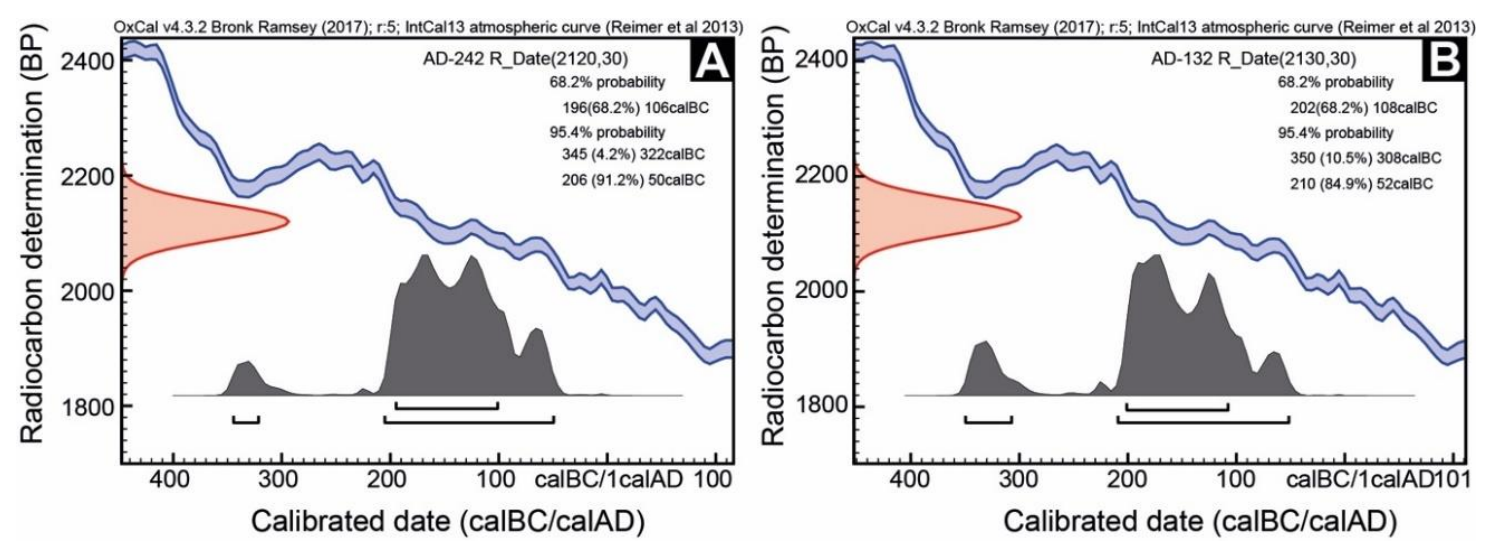

Figure 10. Calibrated ${ }^{14} \mathrm{C}$ dates of the binder from the: (A) AD-242 mortar sample and (B) AD-132 mortar sample obtained with OxCal v 4.1.7 [52] and IntCal09 atmospheric data [53].

\section{Conclusions}

The results of this study have provided information about the technological and chronological aspects of the mortars at the Arroyo de la Dehesa de Velasco site.

The mortars were manufactured in a multilayer system formed by several layers with different thicknesses. Ceramic fragments or powder were added to improve resistance to moisture and the durability of the walls. This multilayer approach agrees with Roman technology recipes written by classical authors and applied by skilled artisans.

Petrographic and mineralogical studies allow to determine the raw materials' provenance area. The only outcrop of Mesozoic limestones in the surroundings of the site, close to Ciudad de Osma-Burgo de Osma, were used to elaborate both lime and aggregates in the floor substrates. Both aggregates Cenozoic and Quaternary siliceous sands from areas close to the site were used. Moreover, the occurrence of kaolinite allows to set the sand provenance to the Oligocene materials.

The petrographic study reveals that the craftsmen followed the theoretical Roman technical guidelines with minor or no variations.

The binder $0.5-2 \mu \mathrm{m}$ fraction of layers without ceramic fragments were selected to perform radiocarbon dating, indicating that the building construction occurred during the first century BC.

Author Contributions: J.J.E. and C.A.F. executed the archaeological study, the sampling strategy and collected the samples; A.A.-O. performed the petrographic analysis and wrote the paper; M.C.Z. carried out the XRD mineralogical study and contributed to writing and reviewing the paper; L.A.O. arranged the funding, the project administration, the geochemical study and contributed to writing and reviewing the paper; G.P.-A. performed the sample preparation and mineralogical study for radiocarbon dating. All authors contributed to discussion of results of this study. All authors have read and agreed to the published version of the manuscript.

Funding: This study was partially supported by the T1193-13 project of the Basque Country Government.

Acknowledgments: We thank anonymous reviewers for constructive comments and suggestions which improved the manuscript. The authors would also like to thank Peter Smith for language assistance.

Conflicts of Interest: The authors declare no conflict of interest regarding this manuscript. 


\section{References}

1. Furlan, V.; Bissegger, P. Les mortiers anciens, Historie et essais d'analyse scientifique. Rev. Suiss. D'art Archaéol 1975, 32, 2-14.

2. Cowan, H.J. The Master Builders: A History of Structural and Environmental Design from Ancient Egypt to the Nineteenth Century; John Willey \& Sons: New York, NY, USA, 1977; pp. 1-299.

3. Malinowski, R. Ancient mortars and concretes: Aspects of their durability. In History of Technology; Hall, A.R., Smith, N., Eds.; Mansell: London, UK, 1982; 7th annual Volume, pp. 89-101.

4. Von Landsberg, D. The history of lime production and use from early times to the industrial revolution. Zem. Kalk-Gips 1992, 45, 199-203.

5. Hughes, J.J.; Válek, J. Mortars in Historic Buildings: A Review of the Conservation, Technical and Scientific Literature; Historic: Edinburgh, Scotland, 2003; pp. 1-88.

6. Moropoulou, A.; Bakolas, A.; Anagnostopoulou, S. Composite materials in ancient structures. Cem. Concr. Comp. 2005, 27, 295-300. [CrossRef]

7. Válek, J.; Hughes, J.J.; Groot, J.W.P. Historic Mortars: Characterization, Assessment and Repair; RILEM Bookseries; Springer: New York, NY, USA, 2012.

8. Artioli, G.; Secco, M.; Addis, A. The Vitruvian legacy: Mortar and binders before and after the Roma world. In The Contribution of Mineralogy to Cultural Heritage; Artioli, G., Oberti, R., Eds.; The Mineralogical Society: Middlesex, UK, 2019; Volume 20, pp. 151-202. [CrossRef]

9. Ortega, L.A.; Zuluaga, M.C.; Alonso Olazabal, A.; Insausti, M.; Ibáñez, A. Geochemical characterization of archaeological lime mortars: Provenance inputs. Archeometry 2008, 50, 387-408. [CrossRef]

10. Sanjurgo-Sánchez, J.; Trindade, M.J.; Blanco-Rotea, R.; Benavides García, R.; Fernández Mosquera, D.; Burbidge, C.; Prudencio, M.I.; Dias, M.I. Chemical characterization of historic mortars from the Santa Eulalia de Bóveda temple, NW Spain. J. Archaeol. Sci. 2010, 37, 2346-2351. [CrossRef]

11. Santos Silva, A.; Adriano, P.; Magalhaes, A.; Pires, J.; Carvalho, A.; Cruz, A.J. Characterization of historical mortars from Alentejo's religious buildings. Int. J. Archit. Herit. 2010, 4, 138-154. [CrossRef]

12. Miriello, D.; Barca, D.; Pecci, A.; De Luca, R.; Crisci, G.M.; López Luján, L.; Barba, L. Plasters from different buildings of the Sacred Precinct of Tenochtitlan (Mexico City): Characterization and provenance. Archaeometry 2015, 57, 100-127. [CrossRef]

13. Moropoulou, A.; Bakolas, A.; Bisbikou, K. Investigation of the technology of historic mortars. J. Cult. Herit. 2000, 1, 45-58. [CrossRef]

14. Kirca, Ö. Ancient binding materials, mortars and concrete technology: History and durability aspects. In Structural Analysis of Historical Constructions; Modena, C., Lourenço, P.B., Roca, P., Eds.; Taylor \& Francis Group: London, UK, 2005; pp. 87-95.

15. Pavia, S.; Caro, S. An investigation of Roman mortar technology through the petrographic analysis of archaeological material. Constr. Build. Mater. 2008, 22, 1807-1811. [CrossRef]

16. Miriello, D.; Barca, D.; Crisci, G.M.; Barba, L.; Blancas, J.; Ortiz, A.; Pecci, A.; Lopez Luján, L. Characterization and provenance of lime plasters from the Templo Mayor of Tenochtitlan (Mexico City). Archaeometry 2011, 53, 1119-1141. [CrossRef]

17. Tenconi, M.; Karatasios, I.; Bala'awi, F.; Kilikoglou, V. Technological and microstructural characterization of mortars and plasters from the Roman site of Qasr Azraq, in Jordan. J. Cult. Herit. 2018, 33, $100-116$. [CrossRef]

18. Miriello, D.; Barca, D.; Bloise, A.; Ciarallo, A.; Crisci, G.M.; De Rose, T.; Gattuso, C.; Gazineo, F.; La Russa, M.F. Characterisation of archaeological mortars from Pompeii (Campania, Italy) and identification of construction phases by compositional data analysis. J. Archaeol. Sci. 2010, 37, 2207-2223. [CrossRef]

19. Kramar, S.; Zalar, V.; Urosevic, M.; Körner, W.; Mauko, A.; Mirtič, B.; Lux, J.; Mladenović, A. Mineralogical and microstructural studies of mortars from the bath complex of the Roman villa rustica near Mošnje (Slovenia). Mater. Charact. 2011, 62, 1042-1057. [CrossRef]

20. Pecci, A.; Miriello, D.; Barca, D.; Crisci, G.M.; De Luca, R.; Ortiz, A.; Manzanilla, L.R.; Blancas, J.; Barba, L. Identifying a technological style in the making of lime plasters at Teopancazco (Teotihuacan, México). Archaeol. Anthropol. Sci. 2018, 10, 315-335. [CrossRef] 
21. Miriello, D.; Bloise, A.; Crisci, G.M.; De Luca, R.; De Nigris, B.; Martellone, A.; Osanna, M.; Pace, R.; Pecci, A.; Ruggieri, N. New compositional data on ancient mortars and plasters from Pompeii (Campania-Southern Italy): Archaeometric results and considerations about their time evolution. Mater. Charact. 2018, 146, 189-203. [CrossRef]

22. Hale, J.; Heinemeier, J.; Lancaster, L.; Lindroos, A.; Ringbom, A. Dating Ancient Mortar. Am. Sci. 2003, 91 , 130-137. [CrossRef]

23. Heinemeier, J.; Jungner, H.; Lindroos, A.; Ringbom, A.; von Konow, T.; Rud, N. AMS ${ }^{14}$ C dating of lime mortar. Nucl. Instrum. Methods Phys. Res. Sect. B Beam Interact. Mater. At. 1997, 123, 487-495. [CrossRef]

24. Lindroos, A.; Heinemeier, J.; Ringbom, Å.; Braskén, M.; Sveinbjörnsdóttir, Á. Mortar dating using AMS ${ }^{14} \mathrm{C}$ and sequential dissolution: Examples from medieval, non-hydraulic lime mortars from the Åland Islands, SW Finland. Radiocarbon 2007, 49, 47-67. [CrossRef]

25. Nawrocka, D.M.; Michczynska, D.J.; Pazdur, A.; Czernik, J. Application of radiocarbon method for dating of lime mortars. Geochronometria 2005, 24, 109-115.

26. Ringbom, Å.; Lindroos, A.; Heinemeier, J.; Sonck-Koota, P. 19 years of mortar dating: Learning from experience. Radiocarbon 2014, 56, 619-635. [CrossRef]

27. Marzaioli, F.; Nonni, S.; Passariello, I.; Capano, M.; Riccio, P.; Lubritto, C.; De Cesare, N.; Eramo, G.; Quiros Castillos, J.A.; Terrasi, F. Accelerator mass spectrometry ${ }^{14} \mathrm{C}$ dating of lime mortars. Methodological aspects and field study application at CIRCE (Italy). Nucl. Instrum. Methods Phys. Res. Sect. B Beam Interact. Mater. At. 2013, 294, 246-251. [CrossRef]

28. Hajdas, I.; Lindroos, A.; Heinemeier, J.; Ringbom, Å.; Marzaioli, F.; Terrasi, F.; Passariello, I.; Capano, M.; Artioli, G.; Addis, A.; et al. Preparation and dating of mortar samples-mortar dating inter-comparison study (MODIS). Radiocarbon 2017, 59, 1845-1858. [CrossRef]

29. Peroni, S.; Tersigni, C.; Torraca, G.; Cerea, S.; Forti, M.; Guidobaldi, F.; Rossi-Doria, P.; De Rege, A.; Picchi, D.; Pietrafitta, F.J.; et al. Lime based mortars for the repair ancient masonry and possible substitutes. In Mortars, Cements, and Grouts Used in the Conservation of Historic Buildings-Mortiers, Ciments et Coulis Utilizes Dans la Conservationdes Batiments Historiques; Symposium ICCROM: Rome, Italy, 1981; pp. 63-100.

30. Groot, C.J.W.P.; Bartos, P.J.M.; Hughes, J.J. Historic mortars: Characteristics and test- concluding summary and state-of-the-art. In Historic Mortars: Characteristics and Tests; Bartos, P., Groot, C., Hughes, J.J., Eds.; RILEM Publications: Cachan Cedex, France, 2000; pp. 443-454.

31. Elert, K.; Rodríguez-Navarro, C.; Sebastián Pardo, E.; Hansen, E.; Cazalla, O. Lime mortars for the conservation of historic buildings. Stud. Conserv. 2002, 47, 62-75.

32. Rodríguez-Navarro, C. Binder in historical building: Traditional lime in conservation. In International Seminar on Archaeometry and Cultural Heritage: The Contribution of Mineralogy; Herrero, J.M., Vendrell, M., Eds.; Soc España de Miner Seminars: Madrid, Spain, 2012; pp. 91-112.

33. Torney, C.; Forster, A.; Szadurski, E.M. Restoration mortars in conservation work: Considerations \& compatibility. In Proceedings of the 3rd Historic Mortars Conference, Glasgow, Scotland, 11-14 September 2013.

34. Pacheco-Torgal, F.; Labrincha, J.A.; Leonelli, C.; Palomo, A.; Chindaprasirt, P. Handbook of Alkali-Activated Cements, Mortars and Concretes, 1st ed.; Woodhead Publishing, Elsevier: Amsterdam, The Netherlands, 2014; p. 852.

35. Kurtis, K.E. Innovations in cement-based materials: Addressing sustainability in structural and infrastructure applications. Mat. Res. Soc. Bull. 2015, 40, 1102-1109. [CrossRef]

36. Liew, K.M.; Sojobi, A.O.; Zhang, L.W. Green concrete: Prospects and challenges. Constr. Build. Mater. 2017, 156, 1063-1095. [CrossRef]

37. Du, S.; Wu, J.; Alshareedah, O.; Shi, X. Nanotechnology in cement-based materials: A review of durability, modeling, and advanced characterization. Nanomaterials 2019, 9, 136. [CrossRef]

38. Da Silva, M.; de Brito, J.; Veiga, R. Incorporation of fine plastic aggregates in rendering mortars. Construct. Build. Mater. 2014, 71, 226-236. [CrossRef]

39. Fan, M.; Fu, F. Advanced High Strengh Natural Fibre Composites in Construction, 1st ed.; Fan, M., Fu, F., Eds.; Woodhead Publishing, Elsevier: Amsterdam, The Netherlands, 2016; p. 596.

40. Vitruvius Pollio, M. The Architecture; Priestly and Weale: London, UK, 1826.

41. Bostock, J.; Riley, H.T. The Natural History of Pliny; Bohm HG: London, UK, 1857. 
42. Ruiz Fernández de la Lopa, V.; Valverde Hernández, M. Memoria Mapa Geológico España 1:50.000 n. 377 ; IGME: Madrid, Spain, 1991.

43. García Merino, C. Uxama I (Campañas de 1976 y 1978): Casa de la Cantera, Casa del Sectile y "el Tambor"; Instituto de Conservación y Restauración de Bienes Culturales: Madrid, España, 1995; p. 170.

44. García Merino, C. Urbanización y Ordenación del Territorio en Uxama Argaela. Mesa Redonda; Emergência e Desevolvimento das Ciudades Romanas no Norte da Peninsula Ibérica: Porto, Portugal, 1999; pp. 191-221.

45. García Merino, C. Población y Poblamiento en Hispania Romana. El Conventus Cluniensi; Universidad de Valladolid: Valladolid, España, 1975.

46. García Merino, C. Las raíces históricas de la sede episcopal oxoniense. Aproximación a la etapa tardo-antigua de Uxama. In Proceedings of the Semana de Estudios históricos de la Diócesis de Osma, Soria, Spain, 15-17 September 1997; Universidad Alfonso VIII y Diputación Soria: Soria, Spain, 2000; Volume 1, pp. 179-196.

47. Dohijo, E. Evolución y transformación urbana de las ciudades del Alto Valle del Duero durante la Antigüedad Tardía. Espac. Urbanos Occidente Mediterráneo 2011, S. VI-VIII, 219-228.

48. Artioli, G.; Secco, M.; Addis, A.; Bellotto, M. Role of Hydrotalcite-Type Layered Double Hydroxides in Delayed Pozzolanic Reactions and their Bearing on Mortar Dating Cementitious Materials: Composition, Properties, Application; Pöllmann, H., Ed.; De Gruyter: Berlin, Germany, 2017; pp. 147-158. [CrossRef]

49. Ponce-Antón, G.; Ortega, L.A.; Zuluaga, M.C.; Alonso-Olazabal, A.; Solaun, J.L. Hydrotalcite and hydrocalumite in mortar binders from the medieval castle of Portilla (Álava, north Spain): Accurate mineralogical control to achieve more reliable chronological ages. Minerals 2018, 8, 326. [CrossRef]

50. Nonni, S.; Marzaioli, F.; Mignardi, S.; Passariello, I.; Capano, M.; Terrasi, F. Radiocarbon dating of mortars with a pozzolana aggregate using the Cryo2SoniC protocol to isolate the binder. Radiocarbon 2018, 60, 617-637. [CrossRef]

51. Ortega, L.A.; Zuluaga, M.C.; Alonso-Olazabal, A.; Murelaga, X.; Insausti, M.; Ibañez-Etxeberria, A. Historic lime-mortar ${ }^{14} \mathrm{C}$ dating of Santa María la Real (Zarautz, northern Spain): Extraction of suitable grain size for reliable ${ }^{14} \mathrm{C}$ dating. Radiocarbon 2012, 54, 23-36. [CrossRef]

52. Ramsey, C.B.; Scott, M.; van der Plicht, H. Calibration for archaeological and environmental terrestrial samples in the time range 26-50 ka cal BP. Radiocarbon 2013, 55, 2021-2027. [CrossRef]

53. Reimer, P.J.; Bard, E.; Bayliss, A.; Beck, J.W.; Blackwell, P.G.; Ramsey, C.B.; Buck, C.E.; Cheng, H.; Edwards, R.L.; Friedrich, M.; et al. IntCal13 and marine13 radiocarbon age calibration curves 0-50,000 years calBP. Radiocarbon 2013, 55, 1869-1887. [CrossRef]

54. Boynton, R.S. Chemistry and Technology of Lime and Limestone; Wiley \&Sons: New York, NY, USA, 1980.

55. Bakolas, A.; Biscontin, G.; Moropoulou, A.; Zendri, E. Characterization of the lumps in the mortars of historic masonry. Thermochim. Acta 1995, 269, 809-816. [CrossRef]

56. Hughes, J.J.; Leslie, A.B.; Callebaut, K. The petrography of lime inclusions in historic lime based mortars. Annal. Geolog. Pays Hellen. 2001, 39, 359-364.

57. Mora, P.; Mora, L.; Philipot, P. Conservation of Wall Painting; Butterworth\& Co.: London, UK, 1984.

58. Piovesan, R.; Curti, C.; Maritan, L.; Mazzoli, C. Petrographic and microstratigraphic analysis of mortar-based building materials form the temple of Venus, Pompeii. In Interpreting Silent Artefacts: Petrographic Approaches to Archaeological Ceramics; Quinn, P.S., Ed.; Archaeopress: Oxford, UK, 2009; pp. 65-79.

59. Pachta, V.; Stefanidou, M. Technology of multilayer mortars applied in ancient floor mosaic substrates. J. Archaeol. Sci. Rep. 2018, 20, 683-691. [CrossRef]

60. Alonso-Olazabal, A.; Ortega, L.A.; Zuluaga, M.C.; Ponce-Antón, G.; Jiménez Echevarría, J.; Alonso Fernández, C. Roman mortars of floor substrates and walls from Arroyo de la Dehesa de Velasco site: Petrographic and mineralogical characterization. In Proceedings of the 5th Historic Mortar Conference (HMC), Pamplona, Spain, 19-21 June 2019; Alvarez, J.I., Fernández, J.M., Navarro, I., Durán, A., Sirera, R., Eds.; RILEM Publications S.A.R.L.: Paris, France, 2019; pp. 410-423.

61. Wentworth, C.K. A scale of grade and class terms for clastic sediments. J. Geol. 1922, 30, 377-392. [CrossRef]

62. Powers, M.C. A new roundness scale for sedimentary particles. J. Sed. Res. 1953, 23, 117-119. [CrossRef]

63. Folk, R.L. Petrology of Sedimentary Rocks; Hemphill Publishing Co.: Austin, TX, USA, 1974; p. 170.

64. Jerram, D.A.; Cheadle, M.J.; Hunter, R.H.; Elliot, M.T. The spatial distribution of grains and crystals in rocks. Contrib. Miner. Petrol. 1996, 60-67. [CrossRef]

65. Stephanidou, M.; Pachta, V.; Konopissi, S.; Karkadelidou, F.; Papayianni, I. Analysis and characterization of hydraulic mortars from ancient cisterns and bath in Greece. Mater. Struct. 2013, 47, 571-580. [CrossRef] 
66. Theodoridou, M.; Ioannou, I.; Philokyprou, M. New evidence of early use of artificial pozzolanic material in mortars. J. Archaeol. Sci. 2013, 40, 3263-3269. [CrossRef]

67. Böke, H.; Akkurt, S.; Ipekoglu, B.; Ugurlu, E. Characteristics of bricks used as aggregate in historic brick-lime mortars and plasters. Cement. Concr. Res. 2006, 36, 1115-1122. [CrossRef]

68. Gutman, M.; Lesar Kikelj, M. Wall paintings from the roman Emona (Ljubljana, Slovenia): Characterization of mortar layers and pigments. Archaeometry 2016, 58, 297-314. [CrossRef]

69. Benedetti, D.; Valetti, S.; Bontempi, E.; Piccioli, C.; Depero, L. Study of ancient mortars from roman villa of Polio Felice in Sorrento (Naples). Appl. Phys. A 2004, 79, 341-345. [CrossRef]

70. Puertas, F.; Blanco-Varela, M.T.; Palomo, A.; Ortega-Calvo, J.J.; Saiz-Jiménez, C. Decay of Roman and repair mortars in mosaics from Italica, Spain. Sci. Total Environ. 1994, 153, 123-131. [CrossRef]

71. Robadora, M.; Arroyo, F. Characterization of roman coatings from the roman house in Merida (Spain). J. Cult. Herit. 2013, 14, S52-S58. [CrossRef]

72. Borsoi, G.; Santos Silva, A.; Menezes, P.; Candeias, A.; Mirao, J. Analytical characterization of ancient mortars from the archaeological roman site of Pisoes (Beja, Portugal) 2019. Constr. Build. Mater. 2004, 597-608. [CrossRef]

73. Taylor, H.F.W. Cement Chemistry, 2nd ed.; Thomas Telford Publish: London, UK, 1997. [CrossRef]

74. Hodgkinson, E.S.; Hughes, C.R. The mineralogy and geochemistry of cement/rock reactions: High-resolution studies of experimental and analogue materials. In Chemical Containment of Waste in the Geosphere; Metcalfe, R., Rochelle, C.A., Eds.; Geol. Soc.: London, UK, 1999; pp. 195-213. [CrossRef]

75. Ponce-Antón, G.; Zuluaga, M.C.; Ortega, L.A.; Agirre Mauleon, J. Petrographic and chemical-mineralogical characterization of mortars from the cistern at Amaiur Castle (Navarre, Spain). Minerals 2020, 10, 311. [CrossRef]

76. Maravelaki-Kalaitzaki, P.; Bakolas, A.; Moropoulou, A. Physico-chemical study of Cretan ancient mortars. Cem. Concr. Res. 2003, 33, 651-661. [CrossRef]

77. Ugurlu, E.; Böke, H. The use of brick-lime plasters and their relevance to climatic conditions of historic bath buildings. Constr. Build. Mater. 2009, 23, 2442-2450. [CrossRef]

78. Valverde Hernández, M. Memoria Mapa Geológico España 1:50.000 n. 378; IGME: Madrid, Spain, 1991.

(C) 2020 by the authors. Licensee MDPI, Basel, Switzerland. This article is an open access article distributed under the terms and conditions of the Creative Commons Attribution (CC BY) license (http://creativecommons.org/licenses/by/4.0/). 